|| ISSN(online): 2589-8698 || ISSN(print): 2589-868X ||

International Journal of Medical and Biomedical Studies

Available Online at www.ijmbs.info

NLM (National Library of Medicine ID: 101738825)

Index Copernicus Value 2019: 79.34

Review Article

Volume 5, Issue 8; August: 2021; Page No. 270-274

\title{
THE EFFECT OF HEPATITIS ON DAILY LIFE
}

Dr. Khaled Hassan', Rahaf Mouner Haj Hasan², Fatimah Alkhawajah ${ }^{3}$, Wafa Alshaikh ${ }^{3}$, Wajdan Mohammed Alshehri $^{4}$, Najd Alnojaidi ${ }^{5}$, Fahad Mushbb N Alqahtani ${ }^{6}$, Abdulrahman Hafidh A Alghamdi ${ }^{6}$, Abdullah Hakami ${ }^{7}$, Yahya Al-shareef ${ }^{8}$, Abdulrahman Alruwished ${ }^{9}$, Hanan Saud Atiah Althagafi ${ }^{10}$

${ }^{1}$ Consultant Family Medicine, Saudi Arabia.

${ }^{2}$ Batterjee Medical College, Saudi Arabia.

${ }^{3}$ King Faisal University, Saudi Arabia.

${ }^{4}$ Umm Alqura Uiversity, Saudi Arabia.

${ }^{5}$ Almaarefa University, Saudi Arabia.

${ }^{6} \mathrm{Al}$ Baha University, Saudi Arabia.

${ }^{7}$ Jazan University, Saudi Arabia.

${ }^{8}$ King Khalid University, Saudi Arabia.

${ }^{9}$ Imam Abdulrahman bin Fasial University, Saudi Arabia.

${ }^{10}$ Taif University, Saudi Arabia.

Article Info: Received 02 July 2021; Accepted 17 August 2021

DOI: https://doi.org/10.32553/ijmbs.v5i8.2133

Corresponding author: Dr. Khaled Hassan

Conflict of interest: No conflict of interest.

\section{Abstract}

Background: A descriptive, exploratory, and qualitative study was undertaken to discover changes in the daily lives of hepatitis patients.

Methodology: In October 2011, data from 12 hepatitis B and/or C patients were acquired using a semi-structured interview and thematic content evaluation. Hepatitis B has been diagnosed in the majority of the participants. The diagnosis duration spanned from less than 6 months to 12 years, and the majority of the diagnoses were made through blood donation. Only two patients received interferon. The findings were classified into two categories based on the feelings and replies of the interviewees, as well as some lifestyle adjustments. It was decided that health practitioners must comprehend the extent of phenomena related to the illness process and life with hepatitis.

Keywords: Hepatitis; Nursing; Nursing care; Communicable diseases; Diagnosis; Life change events.

\section{Introduction}

Brazil is undergoing a dramatic epidemiological revolution, but no communicable chronic diseases remain the leading cause of mortality, and infectious disease prevention remains a public health concern. Hepatitis is a serious problem for health services because of its high prevalence, potential complications from acute or chronic manifestations, and the necessity for long-term surveillance. According to the World Health Organization, there are approximately 325 million individuals worldwide who have hepatitis B and 170 million who have hepatitis C, with estimates ranging from 2 to 3 million in Brazil. Furthermore, at least $15 \%$ of the population is now infected with the hepatitis B virus (HBV), with $1 \%$ of those infected with the chronic form of the disease. Between 1999 and 2010, there were 130,354 instances of hepatitis A, 104,454 cases of hepatitis B, and 69,952 cases of hepatitis C, with significant disparities between states in Brazil [1]. It is important to note that the majority of people are uninformed of their serological status, which exacerbates the infection chain. Chronic hepatitis B or C infection is a substantial source of morbidity and mortality worldwide, as well as one of the leading causes of hepatic decompensation, cirrhosis, and hepatocellular cancer. Regardless of the hepatic clinical symptoms linked with extrahepatic manifestations and cognitive alterations, chronic infection can cause increased stress and have a negative impact on patients' quality of life, social interactions, and daily activity output. Hepatitis is thus a major public health concern, not only because of its great incidence, but also because of the risks associated with its acute symptoms, long-term chronification, and the influence it has on infected people. Several studies have found that chronic diseases have an impact on patients' lives, causing changes in psychology and behaviour, including an examination of everyday habits and ways to cope with this new reality [2]. In some situations, the diagnosis of the disease or the initiation of treatment will result in significant changes in the lives of patients. Subjects with hepatitis C, for example, are more confined in their daily activities (job, school, home) and have less faith in the treatment's efficacy, indicating a lower quality of life trend than those without having the disease. Given the complexity of the events associated with the illness process and life with hepatitis, therapies that allow patients to 
transcend the bodily dimension are prioritized in care. In order to do so, health professionals must have attitudes toward identifying the various parts of the biological, cultural, social, and subjective phases of life. The impact of disease on daily life differs from person to person depending on values, attitudes, actions, images, interpretations, and personal and social experiences. As a result, nursing practitioners must recognize the impact of the diagnosis on patients' everyday life from the perspective of patients in order to facilitate their integration and involvement in this culturally varied context. Furthermore, a new approach to nursing care is essential to offer personalised treatment that values the individual as a whole person rather than reductionist and technocratic viewpoints [3]. Given the preceding context, the goal of this study was to identify improvements in the daily lives of people who had been diagnosed with hepatitis [4].

\section{Material and Methods}

\section{Participants and study design}

Patients with hepatitis B or C who were followed by the Hepatology and Infectious Diseases clinic at the University Hospital of Maringá were studied in an exploratory, descriptive, cross-sectional, and qualitative manner. In relation to the care of patients with a suspected or confirmed viral hepatitis diagnosis, the service applies to the 30 towns that make up Paraná's 15th Regional Health Service. The service is provided twice a week, with an average of five appointments each day. In 2011, the infection clinic discovered 87 suspected instances of hepatitis, all of which were evaluated and, once confirmed, monitored. Of the 87 probable cases, 33 had a proven hepatitis B diagnosis, 30 had a confirmed hepatitis C diagnosis, 18 were still being investigated, and 6 had a verified diagnostic of not being sick. The information was gathered in October 2011 through semi-structured interviews in the Maringa University Hospital's private rooms. While waiting for an infectologist consultation, the individuals were contacted, informed of the study's objectives, and offered to join. The interviews were conducted in a private room, with the consent of the interviewees, and guided by a two-part instrument: the first dealt with patient characterisation difficulties, and the second was introduced as follows: Discuss how your daily life has changed since being diagnosed with hepatitis. We spoke with a total of 12 patients. When the data needed to meet the study's goal started to be duplicated, the interviews came to an end. The prerequisites for inclusion in the report were that the person be 18 years old or older, and that he or she have a hepatitis diagnosis. We looked at gender, age, marital status, education, occupation, time of diagnosis, hepatitis type, and interferon use according to the following variables. The interviews were transcribed for data analysis, after which they were subjected to thematic content analysis, pre-analysis, information discovery, processing, and outcome interpretation phases. During the pre-analysis, the speeches were read to identify the points that were significant to the study's goal. The data was codified during the discovery process, which involves converting and aggregating raw data into units in a methodical manner. In the final phase, a categorization was created by classifying the elements based on their similarities and differences, and then regrouping them based on common qualities. The study was established in accordance with the National Health Council's Resolution No. 196/96 and was approved by the Maringá University Hospital's Committee on the Control and Supervision of Academic Activities and Volunteer Services, as well as Maringá State University's Ethics and Research Committee on Human Research (Protocol No. 724-2011). An informed consent form has been signed in duplicate by all subjects. To identify between people and protect their identities, the following codes were employed: Letter I (interviewee), followed by a number indicating the interview's order, and letters $\mathrm{M}$ and $\mathrm{F}$ for identifying males and females, respectively, with another number revealing the informant's identity.

\section{Results}

The characteristics of several subjects are depicted in Chart 1. The majority of them were men, married, and uneducated. The age of the subject varied from 21 to 57 years, averaging 43 years. With the exception of I6 and I12, the respondents were diagnosed with hepatitis after blood donation, and the most common form was hepatitis B. The I2 and I7 interviewees had a chronic form of the condition and were also taking interferon[5].

\begin{tabular}{|c|c|c|c|c|c|c|c|}
\hline Id & Gender & Age & Marital Status & Education & Occupation & Type of hepatitis & Time of diagnosis \\
\hline II & F & 54 & Married & IEE & Janitor & B & 3-4 years \\
\hline 12 & M & 44 & Married & CEE & Builder & $B$ and $C$ & 4-5 years \\
\hline 13 & M & 42 & Married & IEE & Driver & B & $1-2$ years \\
\hline 14 & M & 56 & Married & IEE & Driver & B & $>5$ years \\
\hline 15 & $\mathrm{~F}$ & 56 & Divoreed & IEE & Housewife & $\mathbf{B}$ & $<6$ months \\
\hline 16 & $\mathbf{F}$ & 35 & Married & IEE & Sugarcane cutter & B & $<6$ months \\
\hline 17 & M & 21 & Single & CHS & Mechanic & B & $>5$ years \\
\hline 18 & M & 27 & Single & HIS & Art finisher & C & $<1$ year \\
\hline 19 & M & 48 & Married & IEE & Plumber & C & $3-4$ years \\
\hline 110 & $\mathbf{F}$ & 42 & Married & IEE & Babysitter & $\mathbf{B}$ & $>5$ years \\
\hline 111 & M & 57 & Married & HIS & Salesman & $B$ and $C$ & 12 years \\
\hline 112 & $\mathbf{M}$ & 39 & Married & IEE & Builder & B & $<1$ year \\
\hline
\end{tabular}

-IEE/CEE, Incomplete/Complete Elementary Education; IHS/CHS, Incomplete/Complete High School 
Many studies have documented some of the feelings and reactions experienced by interviewees after being diagnosed with hepatitis $\mathrm{B}$ or $\mathrm{C}$, such as concern and fear of transmitting the virus to their partners, a sense of helplessness due to a lack of information about the disease, and the distress of wanting to know how they will manage the disease. My doctor diagnosed me with hepatitis (...) Because I had no idea what it was, I was afraid. I haven't thought anything () (I1, F54, B). I was devastated, horrified, and convinced it was the end of a life-threatening condition... I was worried since I knew nothing about this sickness, but the doctor assured me that I didn't have to be concerned because she would conduct all of the necessary tests to see if it was present (I6, F35, B). The majority of the interviewees (8) reported that the diagnosis was accompanied by unpleasant and troubling feelings, owing to a lack of signs and information regarding the disease. Another emotion discovered was the fear/distress of discovering how they received the condition. I got quite concerned and suspicious. I was curious as to how I came up with it. My husband told me that there was no reason for me to think about it (...). I'm not sure how I acquired it because all I have is my spouse, and he doesn't have sex with anyone else but me () (I1, F54, B)[7]. They said that it is transmitted through intercourse and blood transfusion. In 1979, I received a blood transfusion, but my husband was a truck driver, and there were many women on the road at the time. He was diagnosed with hepatitis after we separated, so that could be why I contracted it... I'm curious if I'm the only one who has contracted that illness (I5, F56, B). According to him, you can get it through sex and a blood transfusion. I received a blood transfusion in 1979, but my husband was a truck driver, and there were a lot of ladies on the road. He found out he had hepatitis after we broke up, therefore that could be why I got it... I'm not sure if I just had that illness (I5, F56, B). I just assumed it wasn't anything I should give to anyone because I didn't want to leave anything to my family (I11, M57, B and C). Because sex is one of the key means of transmitting the disease, it was discovered in the reports of the women investigated that they often associate the infection with their husbands' extramarital affairs, interfering in some manner with the relationship and trust between partners [8]. When it came to the sort of infection, several of the interviewees indicated out situations that they believed were responsible for the infection after being informed by the department about the various mechanisms of transmission of the disease. I was fishing in a little river when the drinking water ran out, and I was compelled to drink river water because I was so thirsty. It happened around 15 years ago. I was dying of thirst since the water was brown. I believe I get it from this water from time to time[9]. When I think about it, I guess I got it when I was a youngster, because I used to go to the dentist a lot as a kid. (...) I've never gotten used to doing my nails (I10, F42, B). One of the most common concerns expressed after a hepatitis diagnosis is the worry of transferring the infection to partners and relatives. The first question I asked my doctor was whether anyone else had hepatitis, and he answered no, so I wasn't concerned. (...) Because I wouldn't want to give it to someone else (I5, F56, B). At the time, I also spoke with my girlfriend and requested her to help me with the exam (...). I became concerned and troubled, wondering whether I had passed on someone; even the beard device my sister used was mine; I became concerned and paid a private doctor to conduct the examination (I8, M27, C).

We have also reported feelings of fear due to confusion about the evolution of diseases. It is important to highlight that during any clinical monitoring, the interviewees reported insecurity about the condition and were concerned about the probability of the disease progressing to the chronic kind. While waiting for the appointment, I6 was sweating and making repetitive motions with her hands, while I 2 shifted her legs while he was being interviewed; both displayed physical indicators of discomfort and anxiety [10].

Post-infection attitudes and practices: The diagnosis of hepatitis, like any other sickness, causes modifications in various living behaviors, which may vary depending on the individual. There have been changes in the way people eat and drink.

The speeches also showed alterations at work and in their interactions. I used to work at night, but after becoming ill, I began taking medication, switched shifts, and began working in the morning. I was afraid of having a horrible night's sleep and of the medicine's side effects (I7, M21, B) [11-13].

\section{Discussion}

Most people are aware that they have been diagnosed with hepatitis as a result of blood donation, which is understandable given that hepatitis is a condition that can have long-term consequences. It is typical for a diagnosis to be made as a result of standard laboratory tests that reveal liver abnormalities. According to a study, blood facilities and banks, hemodialysis clinics, and laboratories are the primary sources of diagnosis. Hepatitis has proven to be tenacious, owing to the difficulty of detecting patients in the acute stage; as a result, preventive interventions aiming at halting the chain of transmission must be improved [14]. The addition of counseling, viral hepatitis testing in primary care, and the implementation of health education programs are all important interventions suggested by the Ministry of Health in order to warn subjects about the hazards of infection and whether they can submit to diagnosis tests. This, however, necessitates prior knowledge of pertinent disease-related content, as well as the identification of elements that indicate greater vulnerability and the user's specific demands. Awareness of communicable disease susceptibility aids in recognizing the health requirements of those who are stigmatized, socially isolated, or anxious. [10-14]. There are some people who have traditionally been barred from health care because of their diet, consumption habits, or sexual choice. Because these are the same 
variables that make drug users, transvestites, prostitutes, and homeless persons more prone to hepatitis, it is critical to increase their access to care while respecting their particular qualities [15]. The emotions and changes in daily life experienced by the study participants as a result of their hepatitis diagnosis confirm what has been stated in the literature: the diagnosis of an infectious and communicable disease brings patients with varying prognoses concerns and uncertainties, especially when it comes to silent and slow diseases. When and how they are informed of the diagnosis, as well as the general public's lack of knowledge about the disease, specifically the mode of transmission, evolution, prognosis, and treatment side effects, among other things, all contribute to subjects' feelings of helplessness and inability to cope with the disease, both feelings and behaviors. It's worth noting that the lack of awareness of specific hepatitis symptoms, as well as the possibility of their chronification in the I1 testimony, are not solely patient-related. Nursing, pharmacy, and biology students at Vale do Araguaia were found to have limited awareness of the same aspects in a study conducted there. Only 20.5 percent of health personnel at a Rio de Janeiro military hospital knew the routes of illness transmission, according to another survey [12-16]. These findings suggest that health professionals should be adequately sensitized to the disease and prepared to provide adequate advice, answer patient questions, and even anticipate them in their approach, cultivating disease awareness that is essential for avoiding complications and promoting selfcare. Furthermore, clinicians must be able to recognize disease symptoms, provide resources to assist patients in dealing with them, and allow patients to participate in disease care and monitoring so that they can create a representation and use it to control their actions as patients process infection information [17]. One of the factors that motivated some of the participants, particularly women, to seek out information about how they had contracted the condition was their lack of awareness of the disease. This is understandable because it is an infectious condition that can be transferred through sex. In these situations, it's natural to associate sexually transmitted disease (STD) infection with one of the couple's extramarital relationships, ruling out alternative possibilities such latency time and other possible mechanisms of infection. It's also worth noting that women are particularly vulnerable to STDs and generally tolerate unprotected sexual activity since they trust their partners due to uneven gender ties [18]. Such issues must be addressed as part of the health-care process. It is therefore critical that practitioners have emotional support, are properly informed about the virus's modes of transmission, prevention, and latency, and are accessible to listen and dialog with patients to clarify their uncertainties and assist them in emotional conflicts, which is polite. I2 and I7 reported psychological symptoms after starting interferon therapy, including the influence on their daily life, that are similar to the adverse effects described in the literature. The only FDA-approved treatment modality that can be used alone or in combination with ribavirin is interferon.
Approximately $20-40 \%$ of patients who take this drug may experience depression, anxiety, difficulty concentrating, apathy, sleep disorders, irritability, and even suicidal impulses, symptoms that may have a negative impact on the course of the disease due to disruptions in care and improvements in quality of life[19]. In such cases, the presence of a psychological evaluation procedure for interferon-treated patients will allow for the tracking of psychological symptoms and the need for intervention, as well as the recognition of key issues faced by patients during care, thus providing incentives to develop interventions that are compatible with the needs discovered. Nurses, along with psychologists, must become more alert in order to spot depressed signs early. A higher number of visits is expected for patients with chronic disorders including hepatitis and depression, which affects the cost of care. They are unable to carry out daily tasks, resulting in a decrease in quality of life, an increase in somatic complaints, problems responding to disease-related unpleasant symptoms, and may be less compliant with prescription medicine, as well as a higher risk of mortality. Furthermore, it is critical to note that understanding the problems faced by patients with chronic diseases, as well as the ways employed by individuals who adjust to these poor conditions, may aid physicians in developing more effective intervention systems for those with adaption concerns. Participants in this study indicated that they were unsure if the symptoms they were experiencing were related to the drugs they were taking, implying, to some extent, a failure to interact with health care providers, since prior knowledge of adverse drug effects allows patients to approach treatment more positively. Given that it is not always possible to avoid the occurrence of side effects, patients and doctors must be alert to their occurrence in order to recognize them early, which stimulates monitoring and improves adherence to treatment. Patients and families must be able to easily identify disease manifestations and be advised of the effectiveness of the treatment and the need to stick to it, despite the presence of side effects, by health practitioners who must be prepared to recognize problems faced by patients who use the drug and to provide consistent and reliable information on side effects. A chronic disease diagnosis can have a long-term impact on a patient's life. As people adjust to new demands and conquer new problems and barriers, as well as how they manage with themselves and their wellness, this new condition necessitates adjustments in their lifestyle, relationships, and attitudes. In the case of hepatitis, patients fear that the condition may advance to a chronic stage, which would result in more significant alterations in numerous parts of their daily lives. Noncompliance with safe sex practices is a frightening circumstance that can have serious consequences for the couple. This suggests a pre-existing issue with maintaining relationship conversation, which is exacerbated when the couple is confronted with a paradoxical situation, such as an STDD diagnosis [17-19]. 


\section{Conclusion}

The outcomes of the study show that living with a hepatitis $\mathrm{B}$ or $\mathrm{C}$ diagnosis impacts a variety of emotions and causes suffering and behavioral changes that negatively impact patients' quality of life. Uncertainties about the diagnosis, a lack of professional awareness of the disease, the risk of persistent infection, the route of transmission, and worry and anguish induced by drug reactions pervade infected patients' thoughts and feelings.

\section{References}

1. Cruz CRB, Shirassu MM, Martinsb WP. Comparação do perfil epidemiológico das hepatites B e C em um Serviço Público de São Paulo. Arq Gastroenterol. 2009;46(3):225-9.

2. Brasil. Ministério da Saúde; Secretaria de Vigilância em Saúde, Departamento de Vigilância Epidemiológica. Manualde aconselhamento em hepatites virais. Brasília; 2005.

3. Brasil. Ministério da Saúde; Secretária de Vigilância em Saúde. Doenças infecciosas e parasitárias: guia de bolso [Internet]. Brasília; 2005 [citado 2011 mar. 5].

4. Disponívelem:http://bvsms.saude.gov.br/bvs/publica coes/guia_bolso_5ed2.pdf [ Links ] Brasil. Ministério da Saúde; Secretaria de Vigilância em Saúde. Plano Nacional de Prevenção e Controle das Hepatites Virais [Internet]. Brasília; 2006 [citado 2011 mar. 5].

5. Disponível em: http://hepato.com/pnhv/Plano\%20_PNHV.pdfSousa VV, Cruvinel KPS. Ser portador de hepatite C: sentimentos e expectativas. Texto Contexto Enferm. 2008;17(4):689-95.

6. Blatt CR, Roda JA, Sander G, Farias MR. Tratamento da hepatite $\mathrm{C}$ e qualidade de vida. Rev Bras Farm. 2009;90(1):19-26.

7. Melo LP, Silva NP, Silva KCL, Ponte MPTR, Gualda DMR. Representações práticas do cuidado com a ferida crônica de membro inferior: uma perspectiva antropológica. Cogitare Enferm. 2011;16(2):303-10.

8. Minayo MCS. O desafio do conhecimento: pesquisa qualitativa em saúde. $11^{\mathrm{a}}$ ed. São Paulo: Hucitec; 2008. p. 219-60.

9. Araújo MAL, Silveira CB. Vivências de mulheres com diagnóstico de doença sexualmente transmissível -DST. Esc Anna Nery Rev Enferm. 2007;11(3):479-86.

10. Nichiata LYI, Bertolozzi MR, Gryschek ALPL, Araújo NVDÁL, Padoveze MC, Ciosak SI, et al. The potential of the concept of vulnerability in understanding transmissible diseases. Rev Esc Enferm USP.

11. CampolinaAG, Dini PS, Ciconelli RM. Impacto da doença crônica na qualidade de vida de idosos da comunidade em São Paulo (SP, Brasil). Ciênc Saúde Coletiva. 2011;16(6):19-25.

12. Ferrari CKB, Savazzi K, Honório-França AC, Ferrari GSL, França EL. Conhecimentos sobre hepatites virais numa amostra de estudantes brasileiros do Vale do Araguaia, Amazônia Legal. Acta Gastroenterol Latinoam. 2012;42(1):120-6.

13. Pinheiro J, Zeitoune RCG. Hepatite B: conhecimento e medidas de biossegurança e a saúde do trabalhador de enfermagem. Esc Anna Nery Rev Enferm. 2008;12(2):258-64.

14. Ávila MP, Freitas AM, Isaac DLC, Bastos ALM, Pena RV. Retinopatia em paciente portador de hepatite $\mathrm{C}$ tratado com interferon peguilado $\mathrm{e}$ ribavirina: relato de caso. Arq Bras Oftalmol. 2006;69(2):255-9.

15. Carlo FS, Lima JF, Sene MC, Rosa NM, Cardoso VH, Aguiar JE. Perfil do portador de hepatite B do Município de Maringá. Saúde Pesq. 2008;1(3):241-6.

16. Barroso MGT, Souza LB. DST no âmbito da relação estável: análise cultural com base na perspectiva da mulher. Esc Anna Nery Rev Enferm. 2009;13(1):123-30.

17. Miyazack MCOS, Domingos NAM, Valério NI, Souza EF, Silva RCMA. Tratamento da hepatite C: sintomas psicológicos e estratégias de enfrentamento. Rev Bras Ter Cogn. 2005;1(1):11928.

18. Carvalho MF, Zanini AC, Camacho JLP, Barone AA. Monitoramento de reações adversas da interferona alfa no tratamento ambulatorial da hepatite C crônica. RBCF Rev Bras Ciênc Farm. 2001;37(1):27-38.

19. Ferreira AIG. Substâncias aditivas como fatores de progressão na Hepatite C crônica [dissertação]. Porto (PT): Instituto de Ciências Biomédicas Abel Salazar, Universidade do Porto; 2007. 